\title{
The policy and policing of language in schools
}

\author{
I A N C U S H I N G \\ Brunel University London, UK
}

\section{A B S T R A C T}

This study investigates cases of language 'policing' as educational language policies, and the way that these are represented across different policy levels. Focusing on UK schools and using discursive approaches to language policy as a theoretical framework, I critically examine the motivations and justifications that institutions provide for designing and implementing policies whereby nonstandardised forms are 'banned', and how these are reported in metalinguistic discourse. Drawing on a range of data including media discourse, policy documents, teacher interviews and linguistic landscapes, I textually trace how educational language policies (re)produce prescriptive and linguicist ideologies, often using metaphors of crime, and often using language as a proxy for social factors such as academic achievement, employability, and standards. Overall, I argue that micro- and meso-level language policies are a partial product of the linguistic conservatism as found within current macro-level educational policy. (Language policy, language policing, schools, language ideologies)*

\section{I N G U IS T I C D E N T IS T R Y}

In his critical description of a 'deficit' approach to language policy and pedagogy in schools, Ronald Carter likens prescriptive practice and ideologies to where teachers and policy makers can come to operate as a 'kind of linguistic dentist, polishing here and there, straightening out, removing decay, filling gaps and occasionally undertaking a necessary extraction' (Carter 1997:21).

Just over twenty years later, Carter's metaphor continues to be a relevant framing device for the way that language - particularly nonstandardised forms - is often conceptualised and stigmatised within educational contexts such as classrooms and policy discourse. In order to examine how this metaphor and its associated ideologies about young people's language might emerge in such contexts, this article assumes that language prescription is part of language policy, adopting a critical discursive approach (e.g. Barakos \& Unger 2016a) in order to trace metalinguistic discourse across policy 'levels', from government-produced curricula through to classroom practice. Here then, critical involves unpacking '[linguistic] strategies for maintaining social power' (Woolard \& Schieffelin 1994:57-58), and discursive involves examining the interplay between policy levels and the degrees of agency 
that policy arbiters such as teachers, management, the media, and government have (e.g. Ricento \& Hornberger 1996).

In this article I show how an additional set of metaphorical terms, related to "policing', provide ways of describing practices where policy arbiters at different levels suppress, control, and regulate stigmatised forms of English in the classroom through oral or written 'corrections'. Whilst recent sociolinguistic critiques of language policing have focused on multilingual contexts (see Muth \& Del Percio 2018), there is limited recent work within L1 education in the UK, and so this research offers a contribution by investigating this through a critical discursive lens. The policing of nonstandardised L1 language in schools is an increasingly pervasive phenomenon that attracts significant media attention, coverage that informs much of the discussion in this article. Linguists have been quick to criticise such practices (e.g. Amir \& Musk 2013; Snell 2013, 2018a; English \& Marr 2015:210-17; Giovanelli 2016), but this work has been limited to a small number of cases, and without detailed reference to the conservatism of current educational policy, the increased emphasis on discipline and standards in schools, and the typically limited degree of teachers' sociolinguistic knowledge. Hence, a critical discursive approach offers a way of interpreting metalinguistic discourse within a broader sociopolitical context, revealing contact points between policy levels and possible reasons for why certain discourses about language emerge. Throughout the article, I also highlight a number of connections between the UK and the US and argue that the same theoretical and methodological way of interrogating language education policies are appropriate for both contexts. These issues are explored further in the following sections, and then taken up again in my analysis of language policing practices.

THEORETICAL A N D METHODOLOGICA L O V E R V I E W

The research in this article employs critical discursive approaches to analysing language policy. Three 'levels' interact in designing, implementing, and enacting policy: micro-level (i.e. teachers), meso-level (i.e. school management), and macro-level (i.e. government produced curricula). As such, I draw on a broad dataset that includes media articles, policy documentation, teacher interviews, and linguistic landscapes in order to textually trace discourse about language policing in schools across these levels and sources, and offer this as a contribution to critical sociolinguistics and educational language policy. My criticism is geared towards systemic, macro-level policies and the reasons for which these come to be appropriated and reproduced at meso- and micro-level by school management and teachers, respectively. I rationalise this approach to unpicking policy discourse in further detail below.

My focus is on the UK, given that this has been the site of major recent changes in educational policy, characterised by a shift towards an increasingly available and explicitly conservative discourse about language, education, and nationhood (e.g. K. Jones 2014). In addition, teachers' linguistic knowledge in the UK is typically 
low (e.g. Cajkler \& Hislam 2002). Since 2013, UK curriculum policy places a greater emphasis on the teaching and learning of clause-level grammar-specifically, standardised English (SE) (e.g. Department for Education 2013a,b; see Cushing 2018 for a criticism) - at the expense of discourse, variation, and nonstandardised forms, and made explicit through policy discourse and grammar tests for young children. I discuss these issues further below, before examining some of the previous work on language policing in L1 educational contexts.

I then critically examine a dataset that is threaded together with discourse about language policing. This dataset consists of curriculum policy documents, a set of UK media articles on language policing in schools, and a set of interviews with teachers, all of whom identified as having engaged with the design and/or implementation of language policies. Many of these teachers cited current curriculum policy as a powerful mechanism that can control and regulate their classroom behaviour. Broadly then, I argue that instances of language policing in schools arise as a result of contact points between macro-level curriculum policy and micro-level aspects of teacher knowledge, and that language policing in schools is endorsed and legitimised by the media, who engage with such policies in uncritical ways.

There are four key findings that emerge from this work, revealed through a critical discursive approach to language policy in schools.

(i) Educational language policies often (re)produce prescriptive discourse without making links to wider structural issues, often using metaphors of crime;

(ii) Newspaper coverage of language policing tends to be supportive of prescriptive policies;

(iii) Teachers often use current curriculum policy as a means to justify language policing; and

(iv) Justifications for language policing across policy levels are often based on the view that language is a proxy for various social factors, such as academic achievement and the maintenance of standards.

A C RITICAL D ISCURSIVE A P PROACH TO L A N G U A G P O L I C Y

Critical discursive approaches to language policy involve tracing trajectories and contact points between different policy layers through the gathering and triangulation of multiple data sources (e.g. Johnson 2009). Tracing connections across these levels requires constant 'interactional work' in order to unpick discourses about language at macro-level and concrete classroom practice at micro-level (Heller 2001:213). As Johnson (2013b) suggests, discursive approaches foreground that the 'meaning' of a language policy is

not just derived from the policy document; it also emerges within a series of speech events within one layer and ACROSS MULTIPLE LAYERS OF LANGUAGE POLICY INTERPRETATION AND APPROPRIATION. (JOhnson 2013b:119, emphasis added) 
This approach offers an affordance then, in that it allows researchers to capture implicit-explicit policy 'creation, interpretation, appropriation and recontextualisation' (Barakos \& Unger 2016b:109), to consider both local and global decisions and practices in language policy, to trace the motivations for these, and to offer solutions or alternatives. Accordingly, it resonates with the aims of critical literacies and critical applied linguistics more broadly, in 'connecting language to broader political concerns' (Pennycook 2001:10) and tracing how power is distributed across society. All policy levels, decisions, and arbiters are dynamic and heterogenous, taking a wide range of forms that result in unpredictable and multilayered interactions that can change over time (Mortimer \& Wortham 2015), and so the "macro, meso and micro' level distinctions are inevitably simplified and 'convenient' labels rather than denoting delineated boundaries (Johnson 2015:171).

Applied to the educational contexts that bear relevance to this article, the first level is the macro-level - national policy in the form of government discourse, curriculum documents, standardised assessments, and marking criteria. The majority of UK schools follow the National Curriculum (NC), a prescribed programme of study first introduced in 1988 in order to standardise classroom content. Although the content of the NC has undergone various iterations since its introduction, criticisms have consistently pointed to a didactic encroachment on classroom practice that has curtailed teacher autonomy and deprofessionalised teachers (e.g. Clark 2001, 2010; Gibbons 2017:61-83). I discuss the current version of the NC, implemented in 2014, in closer detail in the following section.

The second tier, the meso-level, is the local policy of the school, taking forms such as a department's marking policy, a school-wide literacy programme, or the languages made un/available for students to learn. One meso-level form in particular - posters on classroom and corridor walls that serve to regulate language use - is of particular interest here, taken as linguistic landscapes (Van Mensel, Vandenbrouke, \& Blackwood 2017), which are designed and deployed as a system of control. Meso-level policy is typically shaped by macro-level policy, due to the hierarchical ways in which power is distributed. For instance, the current $\mathrm{NC}$ emphasises the learning of traditional, clause-level grammar, and so schools have significantly changed their policies in order to incorporate this (Cushing 2018).

The final tier, the micro-level, is the policy that individual teachers hold about language use, typically manifested through classroom decisions about language use. This too can take a range of forms, such as the oral or written 'correction' of stigmatised, nonstandardised forms, or the 'banning' of phrases or words in the classroom. I draw on teacher interview data to examine this level, acknowledging that whilst teachers operate within the parameters set out by the meso- and macro-levels, they undoubtedly retain professional agency and autonomy, and are not just 'cogs in the language policy wheel' (Johnson 2013a:99). Teachers have the potential to be CRITICAL arbiters in the way that they interpret and implement meso- and macro- policy, in that they can 'create a space where dominant 
ideologies are interrogated, and, over time, dismantled with the goal of providing equal language rights for all' (Alim 2010:227).

My interest in this article lies primarily in the waYs in which the implementation of meso- and micro-level policies are represented and justified in metalinguistic discourse at different policy levels.

\section{UK CURRICULUM POLICY AND LANGUAGE I D E O L O G I E S}

In the UK, NC policy is divided into primary (ages 4-11; Department for Education 2013b) and secondary (ages 11-16; Department for Education 2013a) and includes both general and subject specific policies. The current version of the NC was introduced in 2014 by the Conservative government, spearheaded by the then Secretary of State for Education, Michael Gove, and included major changes to curriculum content and assessment procedures. It continues to be widely criticised for its nationalistic ideologies, with monocultural and Anglocentric emphases on exclusively British literature and propagandist history (e.g. Yandell 2017) and the promotion of 'core factual knowledge' pedagogies (Gove 2013) over creativity and critical inquiry.

The NC positions SE as the most desirable variety of English, with students being required to 'speak clearly and convey ideas confidently using standard English' (Department for Education 2013a:10). Teachers, too, are required to uphold this, assigned 'responsibility for promoting high standards of literacy, articulacy and the correct use of standard English' (Department for Education 2013c:11). Grammatical work is focused at clause-level, with no distinction between spoken and written language, and little recognition of linguistic variation or the social value of regional forms. One of Gove's changes at primary school level was the implementation of mandatory grammar, punctuation, and spelling (GPS) tests, following 'expert' recommendations that grammar could and should be tested, on the grounds that there are "clear "right" and "wrong" answers' (Department for Education 2011:60). ${ }^{1}$ In these positivist tests, students are required to identify grammatical constructions in decontextualized sentences, and 'correct' any examples of nonstandardised language. For example, a question from the 2017 paper requires students to identify the correct form of the verb to be from a list of options. One option, 'we was waiting in the playground', is deemed to be 'incorrect', despite this being a perfectly acceptable and 'correct' form in many varieties of English (see e.g. Cheshire \& Fox 2009; Levey 2012).

A major criticism of the GPS tests and their associated policy documents then, is in the way that they are underpinned by a prescriptive ideology and societal stigmas, with the use of evaluative adjectives such as 'correct' and 'incorrect' serving to promote SE and 'right ways of speaking' at the expense of nonstandardised forms (see Cushing 2018). Language tests are political instruments, often deployed as a form of 'sanction' against the use and legitimacy of nonstandardised forms, and as one mechanism used to narrow the curriculum, control linguistic use/knowledge, impose discipline, and 
determine social order (Shohamy 2001, 2006:93-109). At micro-level, teachers can come to reproduce these ideologies in their practice, often using a 'rulebook' metaphor, where language is, for example, a 'set of rules dictating what people can and can't do with language' (Cushing 2019:163). Furthermore, curriculum policy dictates that children learn about hyper-formal constructions such as the subjunctive, despite this being an 'archaic' form of the verb in UK usage (Huddleston \& Pullum 2002:1000). Gove's motivation for children learning more about grammar was rooted in his belief that doing so would 'make them more literate' (Gove 2014), despite decades of overwhelming evidence to suggest that decontextualised grammar teaching and testing does nothing to improve reading and writing ability (see Hudson 2001). The grammar tests then, are one vehicle through which prescriptive language policies and agendas are imposed and justified.

There are remarkable similarities with the UK context and the US, which I briefly outline here. These are most notably in the policies of the Common Core State Standards (2010), which insist on children 'demonstrating command of standard English grammar' (Common Core State Standards 2010:25), with limited references to spoken-written differences and language variation (see Poza \& Valdés 2017 and Godley, Carpenter, \& Werner 2007 for a broader critique). Relatedly, Doug Lemov's Teach like a champion programme, ${ }^{2}$ popular with many teachers in the US and the UK, advocates the kind of linguicist, prescriptive policy found across curricula in these countries.

Yes, you should correct slang, syntax, usage, and grammar in the classroom even if you believe the divergence from standard is acceptable... when a student makes a grammatical error merely repeat the error in an interrogative tone: "We was walking down the street?" ... Then allow the student to self-correct. (Lemov 2010:47-48)

Lemov's 'quick-fix' discourse about language correction is not framed with any reference to sociolinguistic theory or consideration, dismissing this on the grounds that SE is the 'language of opportunity' (Lemov 2010:47) and that school is not 'the time and place in which to engage them in a broader sociological discourse on dialect' (Lemov 2010:48). His ideas and 'teaching manuals' have been championed by UK education ministers, including Gove and the current Minister of State for School Standards, Nick Gibb (see Weale 2014), as well as the Teach first fast-track teacher education programme in the UK.

\section{STANDARDISED ENGLISH AND EDUCATIONAL P O L I C Y}

SE has long been the 'legitimate' language of UK education and the 'mainstay' of English teaching since at least the mid 1700s (Watts 1999; Crowley 2003). In tracing this history, Watts reveals how prescriptive grammars were reconditioned into pedagogical materials, with schools reproducing linguistic ideologies about the 'value' of SE that was underpinned by an assimilationist agenda. Discourse from eighteenth and nineteenth century school grammar books revolves around 
linguistic 'purity' and 'perfection', a conceptualisation of language that has remained remarkably steady when compared against current curriculum policy. Government education policy in the UK has consistently featured prescriptive discourse about grammar (see Hudson 2016 for an overview). For instance, the Newbolt Report (Board of Education 1921) assigns teachers the roles of 'language regulators', in order to address 'speech disfigured by vulgarisms' (Board of Education 1921:65) and 'bad English', which can lead to 'bad habits of thought' (Board of Education 1921:10). Attempts to challenge such prescription have come closemost notably in the Language in the national curriculum (LINC) project, a £21 million teacher education programme between 1989-1992 led by Ronald Carter, whose dentist metaphor opened this article. The LINC materials promoted descriptive linguistics, offering students the chance to learn about regional variation and the value of nonstandardised forms, but publication of them was banned by the Conservative government on the grounds that they failed to pay sufficient attention to SE, in a remarkable demonstration of macro-level authority and ignorance of linguistic expertise (see Carter 1996).

Throughout these histories, a pervasive argument for the idea that SE is the 'correct' register for schools is that of 'common-sense' (Cameron 1995; J. Milroy 2001:535-39). The common-sense ideology of a standard language posits that 'when there are two or more variants of some word or construction, only one of them can be right' (J. Milroy 2001:535), and so automatically reduces language to a set of polarised, binary 'answers', much in the same way that current primary school grammar tests are designed. Educational language policies generally foreground that the 'right' variant is SE, and because linguists are often seen to provide arguments that challenge such 'common sense' views, they can be dismissed from language policy decisions in schools, as was the case in the LINC saga, and the case for the current curriculum (see Mansell 2017). In relation to media and policy discourse, criticisms have tended to focus on this common-sense ideology, such as Cameron (1995) who shows how 'scare stories about falling standards' can lead to a 'moral panic' or 'linguistic emergency' (Cameron 1995:89), which serves to further legitimise prescriptive practices around nonstandardised forms.

SE is a variety with classist and racial 'privileges' (e.g. L. Milroy 1999:178-92; Rosa \& Flores 2017), which are reproduced in US-UK educational policy and society more broadly (e.g. Gillborn 2006), and crucially for this article, by the media. Tyler (2013) argues that the UK government and the media actively 'crafts' the stigmatising and marginalising of certain societal groups (such as welfare claimants), in order to garner public support for punitive policy reforms. As such, media metalinguistic discourse provides an important lens through which language ideologies can come to be shaped and implemented. Because curriculum policy and media discourse has typically stigmatised nonstandardised language then, it legitimises acts of language policing under the benevolent guise of giving children 'opportunities' and 'access' to jobs, academic achievement, and economic success. This is taken up further in the next section, and in the discussion sections that follow. 


\section{A NGUAGE POLICING IN SCHOOLS}

Language plays a critical role in reproducing imbalances in power and dominance, especially when powerful policy arbiters have the ability to regulate and control the language of others (e.g. Piller 2016). Applied to educational settings, instances of language policing are typically enacted by policy makers such as teachers and management, who hold institutional power (Fairclough 2014) over students. When this happens, it becomes a 'macro/micro-level language policy-in-process' (Amir \& Musk 2013:152), whereby policy arbiters can appropriate and enact macro-level policies in different ways. For instance, language policing can be in oral or written forms, and can target any variable of a language, or an entire language, such as the 'Official English' (or 'English only') policy, designed to certify English as the official language of the US. ${ }^{3}$ My interest in this article is in the enactment of policies designed to target nonstandardised forms within a given language (in this case, English), and how these relate to and are situated within wider macro-level policies. Although my interest here is the policing of children's language, teachers, too, can be the targets of language policies designed to regulate nonstandardised accents (e.g. Baratta 2018).

In the run-up to and post-implementation of the current UK curriculum, there was a flurry of media articles reporting cases where schools had 'banned' the use of nonstandardised forms. In a discussion of two of these cases, English \& Marr (2015:210-17) suggest that although the school policies were justified under a badge of being 'well-meaning' in seeking to improve literacy rates, they were reflective of the schools' limited knowledge about language (English \& Marr 2015:216), with illogical decisions in banning specific words and misconceptions between spoken and written grammar. Brady's (2015) discussion of one case is geared around survey data from students, the majority of whom identified as speakers of nonstandardised English, but accepted the 'legitimacy' of SE and any classroom sanctions that imposed bans on their own language. The most critical of these studies is from Giovanelli (2016:19), who orientates his criticism of one case using Gee's notion of d/Discourse (Gee 2012), to show how different levels of knowledge about language can feed into different belief systems about how the world 'ought to be' and how instances of language policing are often enacted by teachers who have limited linguistic knowledge. Indeed, studies have shown that teachers' linguistic knowledge is typically low, as a result of few linguistics graduates entering into teaching, and a lack of government support in providing teachers with opportunities for professional development (see Cajkler \& Hislam 2002). This paper builds on this work by approaching language policies from a critical discursive approach, drawing on a wider range of data in order to better trace connections between policy levels, and to situate an understanding of language ideologies in schools within a broader context.

Taken together, these discussions of language policing strongly argue for micro-/meso-level linguistic knowledge as a powerful force in policy interpretation and implementation. Language policing in educational contexts has various 
consequences, from negatively affecting students' confidence, motivation, and desire to participate in classroom activities through to the stigmatisation of young people's ways of using language (e.g. Trudgill 1975; Cheshire 1982; MacRuairc 2011a,b; Snell 2013). In addition, sociolinguists have repeatedly made the case that deficit attitudes towards speakers using nonstandardised forms can lead to those speakers feeling insecure and facing threats to their identity (e.g. Bucholtz \& Hall 2005; Moore 2011; Snell 2018b).

\section{A T A A D METHODS}

In order to conduct a critical discursive analysis of educational language policies, I draw on data from three sources representing different policy levels: education policy documents (e.g. Department for Education 2013a,b,c), a small corpus of UK newspaper articles about language policing in schools, and a set of interviews with sixteen primary school teachers.

For the newspaper data, sampling was restricted to national newspapers that focused on the policing of children's language. Twenty-eight articles were collected, acquired through internet searches using the following terms: school, language, dialect, and ban. Articles were published between 2008 and 2019 and covered the political spectrum of the UK press, with eighteen being aligned to right-wing political views and ten to the left. Fifteen articles came from tabloid newspapers; thirteen came from broadsheets. There were seven 'cases' of language policing that were considered, each from a different school. The names of each school have been retained, on the grounds that these are cases reported in national newspapers and widely available online. In naming the schools here, it is not my intention to 'shame' these institutions but to use media representations of their language policies as a springboard to discussing wider issues about language policing in educational contexts. Although the media plays an important role in shaping public views about language, this data must be taken with caution, with stories often being sensationalised in order to meet readership demands, which can raise questions of authenticity. For instance, Jaworski (2018:346) suggests that the media " "pick up" certain issues, however small, and turn them into stories, moral panics and debates' (see also Fowler 1991; Cameron 1995). Nonetheless, the media provide an important and powerful platform for the representation of language issues and the kinds of linguistic ideologies they choose to promote to their audiences.

To trace connections between media discourse and micro-macro policy, I conducted semi-structured interviews with sixteen practicing primary school teachers from eleven different UK schools, between March and May 2018. All of these had identified as being involved with language policies to some extent, either designing one for their own classroom, or working under a meso-level school management one. They responded to a call for participants through my own contact network of teachers, and none had received any formal training in linguistics, which is typical for UK school teachers (e.g. Cajkler \& Hislam 2002). They all 
identified as White British. Interviews lasted between fifteen and thirty-five minutes, focusing on teachers' views of language within the current curriculum, their own beliefs about language, and the nature of their own language policies. As such, they provided me with an insight into the 'lived experience' of microlevel policy makers (e.g. Garvis 2015), allowing me to better trace connections across policy levels and in this way triangulating data to conduct the kind of discursive analysis I advocated for in the opening sections to this article. All interviews were broadly transcribed, and all names that appear in this article are pseudonyms.

The media articles and interview transcripts were first read, and then thematically coded using NVivo software. Following Elliot's (2018) steps for a flexible and pragmatic approach to coding, I used a blend of deductive and inductive methods, beginning with some broad themes about language policy and language ideologies, and allowing new themes to emerge as I coded. For instance, 'parent' codes (e.g. language linked to other social factors) were then split into 'child' codes (e.g. language linked to employment and language linked to academic achievement). This process generated a final coding framework, which was then used to check against all articles and coding decisions in order to ensure consistency. The most prominent themes are used to steer the basis of the analytical sections to follow.

\section{A N A L Y S I S}

\section{Overview}

An overall picture of the data reveals a dominant prescriptive discourse, with the ubiquitous use of evaluative adjectives and adverbs such as 'poor', 'incorrect', and '[speak] properly' used to describe nonstandardised language. The articles and teachers were largely supportive of the policies, often engaging with them in uncritical ways without reference to systemic issues such as curriculum change. As per discussions within critical sociolinguistics (e.g. Piller 2016), language was frequently used as a proxy for other social factors such as crime, economic prosperity, employment chances, academic achievement, and the maintenance of social standards, all of which I discuss further below. Following Cameron (1995) and Cushing (2019), 'grammar' in schools was used as a metaphorical correlate for a 'cluster of related political and moral terms: order, tradition, authority, hierarchy and rules' (Cameron 1995:95), legitimising a causative relationship between 'bad grammar' and 'bad behaviour'.

Language policies took various forms, from explicit written guidelines (such as the Teachers' standards and assessment criteria for tests) to implicit de facto policies that emerged during teacher interviews. One type of explicit policy was in the form of posters, signs, and letters, taken here to be linguistic landscapes (Van Mensel et al. 2017), or even METAlinguistic landscapes, which were placed on classroom walls, corridors, and outside school gates, or sent home to parents. These landscapes varied in their exact contents but tended to list specific examples of nonstandardised forms, e.g. 'coz' and 'innit' (Fishwick 2013), which were banned under the policy, generally 
without any justification or details on what 'punishments' rule-breakers might receive. As such, they are a type of 'surveillant landscape' (R. Jones 2017), in that they served the function of regulating and monitoring 'unlawful' behaviour. Theo, a teacher in his third year of practice, talked about a surveillant landscape that he had designed as part of his own language policy, implemented in response to what he felt was a growing number of nonstandardised forms appearing in classroom discourse, and his felt need to, in Carter's terms, 'extract' them.

I have a poster behind my desk that says I'm watching them all (.) sometimes I say the classroom is a crime scene [laughter] it's got that picture from big brother on it (.) but I made it say Mr Price is watching your grammar. (Theo)

Theo's poster is shown in Figure 1, which makes clear intertextual connections to George Orwell's 1984, a fictional dystopian world of governmental surveillance and control.

Although Theo mitigates this through humour, I suggest that his surveillant landscape is representative of macro-level curriculum policy in the way that it serves a regulatory function in controlling young people's nonstandardised language.

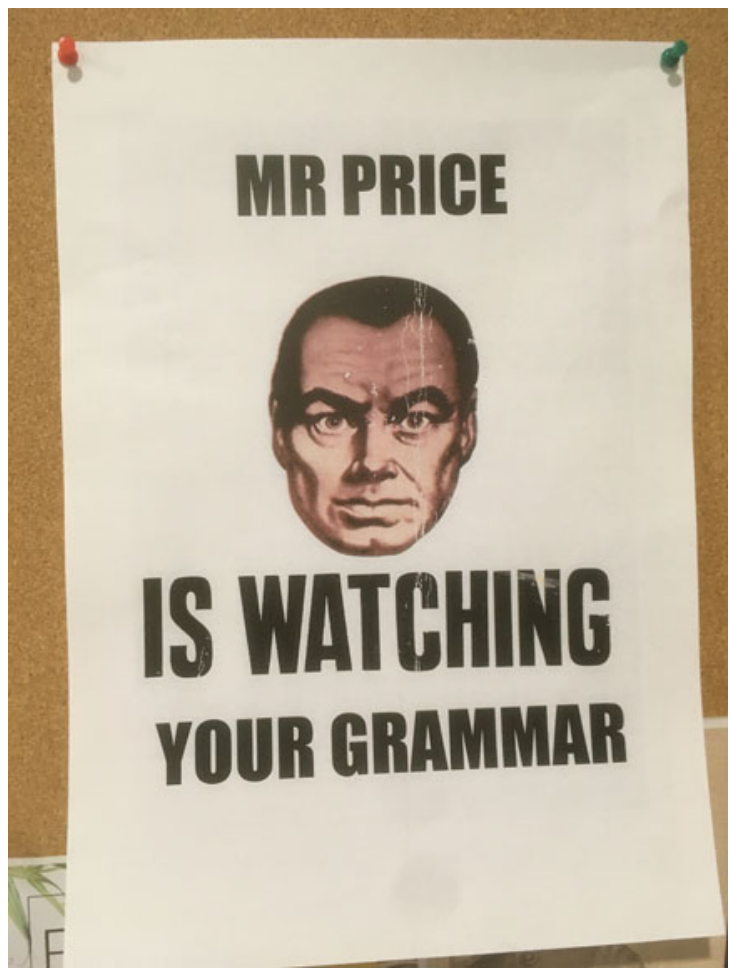

FIGURE 1. A surveillant landscape. 
Received amidst an educational policy context that champions SE, the poster serves as one artefact that constructs an atmosphere that is characterised by prescription, and ultimately, linguicism (Skutnabb-Kangas 1988:13).

In the following sections, my analysis is steered by the prominent themes that emerged as a result of the coding process outlined above, beginning with metaphors such as the 'crime scene', in how Theo chooses to describe a classroom featuring nonstandardised language. My argument is not to suggest that children should be denied opportunities to learn standardised forms of a language, but that a more nuanced understanding is needed in relation to how, in educational contexts, forms of a language may be related to meso- and macro-levels of policy power and the 'crafting' of language stigma and linguicism.

\section{Language crimes}

The process of language 'policing' forms part of a CRIME metaphor, of which there were sixty-one instances across twenty-two media articles, and seventy-six references across sixteen interviews. For instance, in the following examples I have italicised any words that are manifestations of this metaphor.

Posters will be placed around the school displaying the banned words while teachers have been told to listen out and crackdown on rule breakers (Curtis 2016)

Banned words are put into "word jails" on classroom walls (Griffiths \& Henry 2019)

I police things pretty closely in terms of the language they use and the words they say (Rachel)

Following conventions from Lakoff \& Johnson (1980), metaphors occur when one thing (a 'target domain') is understood in terms of another thing (a 'source domain') and can be represented using an $\mathrm{X}$ IS $\mathrm{Y}$ structure, with $\mathrm{x}$ being the target domain and $\mathrm{Y}$ being the source domain. The examples above then, are all realisations of the metaphor of THE USE OF NONSTANDARDISED ENGLISH IS A CRIME. Critical discourse analysts argue that metaphors are ideologically motivated (e.g. Hart 2014), in the sense that the source domain provides a 'lens' through which the target domain is described, and that different lenses can highlight or hide different aspects of each domain, such as policies being 'laws', policy arbiters being 'police', and students being 'criminals'. Over time, metaphors in discourse can come to be a 'conventionalised' part of a speech community's repertoire (e.g. Semino 2008), with groups of people converging on the same sets of metaphors. This notion is important when considering the use of metaphor in language policy/policing discourse, because it can lead to ways of thinking about language that become entrenched and legitimised, such as the CRIME metaphor.

Other 'nonstandardised' issues - all of which bear no relation to language useformed part of many of the policies, especially those reported on in the media, such as 'behaviour' and 'tighter controls on uniform standards' (e.g. Henry 2008). The indexing of language to unrelated social factors is a well-trodden rhetorical trick in conservative discourse about language in schools (e.g. Cameron 1995:78-115), for 
instance, here by Norman Tebbit, who in 1985 was the Conservative Secretary of State for Trade and Industry, speaking on national radio.

If you allow standards to slip to the stage where good English is no better than bad English, where people turn up filthy at school ... all these things tend to cause people to have no standards at all, and once you lose standards then there's no imperative to stay out of crime. (Norman Tebbit, cited in Carter 1994:22)

What has changed from the contexts in which Cameron and Tebbit were writing is that in many present-day schools, policing is much less of a metaphor. Reports suggest that around 5,000 UK schools have their own dedicated police officer, deployed to 'intervene when children step out of line ... and patrol the school grounds' (Paton 2009). The rise in police in schools, a direct consequence of policy initiatives such as the Safer School Partnerships (Department for Children, Schools, and Families 2009) has been linked to a wider shift towards discipline, surveillance, and control throughout society in general (see Henshall 2018). Related to this is the reference that many of the language policies make to a 'zero-tolerance' approach to nonstandardised language, such as by Kyle, who suggested such an approach 'set the boundaries in terms of how [children] are allowed to speak really nice and clear'. Zero-tolerance is a growing educational ideology in the $\mathrm{UK},{ }^{4}$ originally stemming from US border-force narcotics programs and then appropriated into schools in order to 'show no lenience for certain kinds of student misconduct' (Kafka 2011:2). Figure 2 is an image taken from Awford (2014), showing a letter sent home to parents with details of the language policy and a justification for the zero-tolerance approach.

As well as police, in 2012 the UK government implemented a series of policies designed to promote a 'military ethos' in schools (e.g. Department for Education 2012). These included the opportunity for ex-military personnel to register for the 'Troops to teachers' scheme, a programme designed to fast-track ex-armed service members into teaching, and the availability for military organisations to sponsor and fund schools. This, the 'militarisation of education', has been widely criticised for the ways that it legitimises policing and zero-tolerance behaviour policies, which language can be part of (see Chadderton 2014).

As first alluded to in the previous section, textual traces of the CRIME metaphor were found in micro-level policy, in the interview dataset.

actually I think as teachers we have responsibility for making sure students are speaking correctly and using the correct grammar (.) I like to think of myself as the grammar police and I'll quite happily stop the class make a siren noise and point out an error in somebody's writing or whatever (Theo)

I do think they need to have rules to follow in their language (.) and so yeah I'm like the grammar police and sometimes I feel like I'm on patrol watching what they do and stopping them when they're wrong (Claudia)

Both Theo and Claudia position themselves as language policy arbiters who adopt responsibility for the way that their students use language. There is a discourse of humiliation here ("I'll quite happily stop the class ... and point out an error"; "I'm 


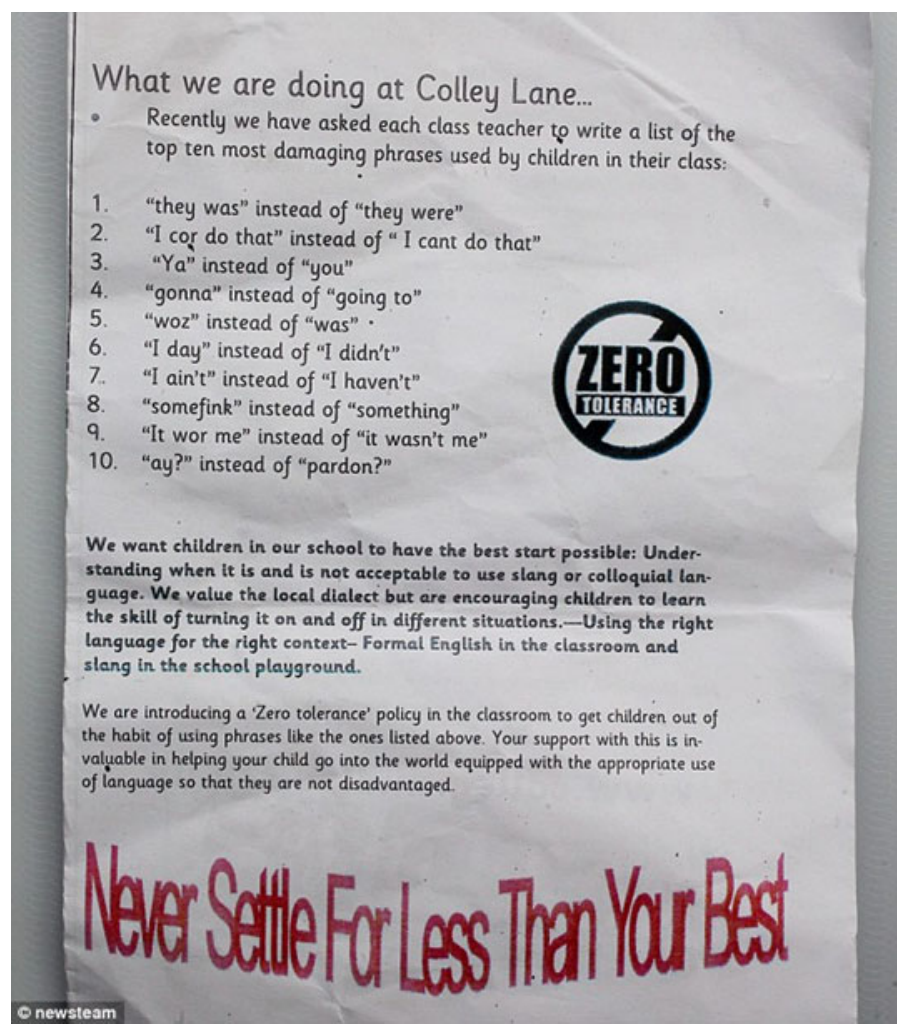

FIGURE 2. A zero-tolerance language policy (from Awford 2014).

on patrol watching what they do"), using metaphors of policing ("grammar police", "siren noise", "crime scene", "patrol"), which resonate with the language used in the media data and frame the classroom as a site of imbalanced power and imposed sanctions, part of which is manifested through language policies.

It is important to frame these discussions as part of a wider criticism towards meso/macro-level policy, and that teachers operate within a power hierarchy themselves. For instance, some participants talked about how their language use had been judged by management against the Teachers' standards document (Department for Education 2013c), part of which requires them to uphold and promote the 'correct' use of SE.

when I've been observed before (.) there's a lot of times that I've been told I have to tell kids off for not speaking properly (.) you know really correcting what they were saying and trying to sort out their ways of speaking and yeah (1) like I should be watching and listening for errors all the time (Ola)

In a sense then, the Teachers' standards is another form of a surveillant landscape: not explicitly displayed on the classroom wall as in Figure 1, but an omnipresent, 
macro-level authoritative eye under which teachers are regulated and controlled (see Perryman, Maguire, Braun, \& Ball 2018 for a further discussion).

This section has drawn on textual traces of the CRIME metaphor across the three levels of language policy in the dataset, showing how language policing at microlevel is often part of a wider policy and ideology that serves to impose control and power on young people and their teachers.

\section{Employment, economy, and academic achievement}

Thematic analysis of the dataset revealed that the most pervasive motivating factor for designing and implementing prescriptive language policies was the idea that using SE would lead to students increasing their employment and economic opportunities (fifty-nine references across nineteen media articles; seventy-two references across sixteen interviews) and enjoying greater academic success (thirty references across fourteen articles; sixty-three references across sixteen interviews). The data revealed that media discourse and policy arbiters often established a direct correlation between a decrease in nonstandardised forms and an increase in financial gain and academic achievement.

A secondary school has instructed its pupils to stop using slang words such as 'hiya', 'cheers' and 'ta', to enhance their prospects of landing a top job. (Shepherd 2012)

because ultimately students need to be able to use language properly in order to get jobs and do well in life and you know (.) we're here to show them how to do that (Ella)

School bans youth slang and sees exam results soar. (Henry 2008)

The link between language, employment, academic success, and economy was a key part of the language policy imposed by schools, despite the fact that these were policies for young children, who in many cases, were a number of years away from finding themselves in situations such as writing a job application or attending a job interview. Language here becomes a proxy for the employability 'enhancement' of students, indexing ideologically related meanings (Eckert 2008) and as something that was seen to increase their chances when 'competing' against other people.

It is all about getting these children ready for that job interview when they can hold their own with people from across the country. (Fricker 2013)

they have to use language correctly if they want to work and earn money and look after themselves and (.) some of them have no chance I think (.) because of the way they use language (David)

really I see my job as preparing them for work once they leave school and language is obviously a crucial thing in that (.) better grammar means a better job basically (Alex)

The data above resonates with Lippi-Green's language subordination process (2012:66-77), whereby 'any speaker of a stigmatized vernacular is promised large returns' if they adopt the standard. Lippi-Green suggests that education is often the 'heart' of the process (Lippi-Green 2012:68), where macro-level 
authoritative bodies (such as a government) first claim control over language, then move on to devaluing stigmatised forms and their speakers by holding up "conformers' as positive examples and promising rewards to those who assimilate to the standard. Traces of this process can be found across policy levels, for instance, in Michael Gove's arguments that illiteracy 'condemns' young people to 'joblessness' (Gove 2014), and in recent rhetoric that the primary school grammar tests are 'working' in eradicating illiteracy (Gibb 2018), despite the narrow view of language that they assess. Macro-level conceptualisations of what constitutes being literate are fixated on the use of SE, and the idea that SE provides 'access' to jobs. This is despite research evidence to suggest that the presence of nonstandardised forms in a person's dialect has a minor impact on overall written and oral literacy ability (see Snell \& Andrews 2016 for a systematic review). What the policies do appear to point to, then, is the ideological associations that SE carries in terms of intellectual ability, and studies have suggested that teachers do indeed tend to evaluate nonstandardised forms in negative terms, despite student ability (e.g. Garrett, Coupland, \& Williams 1999; Godley et al. 2007).

Conceptualising language and language policy in relation to economic viability and employment is underpinned by a neoliberalist discourse where language serves the function of a commodity (e.g. Duchêne \& Heller 2012; Park \& Wee 2012; Holborow 2015) and is aligned with the corporate world and its aims of capital growth. Typically, SE is the variety of English that is assigned the greatest value on the linguistic 'market' (Bourdieu 1991). In this, the school comes to be a site of entrepreneurial activity, with meso-level policies serving to prepare and produce students who are 'linguistically fit' to enter into such a world (see Pennycook 2001) given their competency in SE.

[Standard] English, it is widely perceived, holds the promise of material and social power ... a key to accessing various institutions of power, particularly those of education, employment and government. (Park \& Wee 2012:186)

One school whose policy was covered in the media was Ongar Academy (in Essex, south east England), who indexed formal language with employability in the title of their policy, calling it 'Elocution for employment' (Ongar Academy 2016). The policy gained national media coverage in newspapers and Good morning Britain, a breakfast time news-orientated television show. Drawing on a CONTEST metaphor, the policy frames their pupils as 'competing' and being 'up against' 'Europeans' and 'non-native speakers who ... may be better spoken than them' (Ongar Academy 2016). To do this, the policy lists 'improving the spoken word' and 'ensuring that students are corrected if they lapse into poor spoken habits' in order to 'prepare students for the world of work' (Ongar Academy 2016). It is rather ironic then, that the worth of oracy in UK education has been severely undermined in current curriculum policy, with limited opportunities for studying spoken language and sociolinguistics (see Clayton 2016:78-80). Even more ironically, Ongar Academy's policy defends macro-level policy by championing the kind of 
cultural and language ideologies it promotes and the 'threat' that nonstandardised forms carry.

deeply concerned about the dumbing down of culture in the UK ... children's education and interest in learning face unprecedented threats from the 'culture of stupidity' all around them ... Michael Gove's education reforms are being jeopardised because appearing dumb seems a better way to make a fortune than working hard. (Curtis 2016)

The 'dumbing down', 'culture of stupidity', and 'jeopardisation' of the government's education reforms are equated to the use and presence of nonstandardised language, with some policies citing the influence of reality television shows such as Love island (see Griffiths \& Henry 2019) and The only way is Essex (TOWIE) on students' language. This was picked up on in various articles and interviews, for instance:

SPEAK PROPERLY! Towie language banned from school so pupils can get a job (Anonymous 2016)

I think the kids (.) and the parents I guess (.) watch these programmes which are full of bad grammar and slang you know (.) and they see that and think it's OK to talk like that (David)

TOWIE is a popular programme depicting the everyday lives of a group of young adults, most of whom use vernacular forms associated with the Essex region. Other media articles stigmatise and ascribe negative qualities to Essex voices, judging it to be the 'worst' and 'least attractive' accent in the UK (T. Jones 2013). Nonstandardised forms named in the policy that are deemed to be 'jeopardising' macro-level policy reforms include shortenings (e.g. 'emosh'), contractions (e.g. 'ain't'), informal lexis (e.g. 'geezer'), and intensifiers (e.g. 'literally'). Of course, these forms are not exclusive to TOWIE nor the Essex dialect, but transcend isoglossic boundaries including region and age, and are likely to be features present in the Essexbased teacher's repertoires who were instructed to enact the policy at micro-level.

To summarise this section, the indexical links between nonstandardised language and academic success, employability, and financial prosperity was a prominent theme across the dataset. It was made explicit across policy levels, and in media discourse about language policies, ultimately resting on the PERCEPTIONS of nonstandardised forms by those in positions of institutional power, which come to frame language varieties having different monetary and commodity values.

\section{Language spaces and borders}

In this final analysis section, I briefly examine the place of language 'spaces' and 'borders' and their use as a justification for the implementation of language policies. References to this in the dataset included discourse about certain forms of language being 'permitted' in one designated space but not another, and where boundaries between 'home' and 'school' were challenged (forty-nine references across eighteen media articles; sixty-four references across sixteen interviews).

Spatial language was used across the dataset in order to talk about how it is expected that different spaces ought to yield different forms of language in terms of 
accommodating the 'appropriate' code - for instance, 'turning it on and off in different situations', 'using the right language for the right context', and 'formal English in the classroom and slang in the playground'. In one article (Feltz 2008), 'street slang' is conceptualised as a SUBSTANCE that has the potential to 'seep' from playgrounds into classrooms, with teachers

forced to confront the first generation unable to cobble together the words or phrases necessary to conduct a basic job interview in the Queen's English. (Feltz 2008)

Some schools attempted to extend the policies to students' homes, either by teachers contacting parents directly or by asking children to consider the way they spoke outside of school.

A supporting booklet published by the school aims to get parents supporting the measure at home (Press Association 2013)

If they start speaking properly at home ... then I think that's really important because they can then bring that language to school and so yeah I've asked them to apply all they've learnt about standard English to their home and things (Sara)

What such language touches on is the notion of REGISTER, namely that language varies according to the social context and situation in which it is used. 'Appropriateness' and 'context' were recurring themes used to justify policies, and although these are indeed more in line with the aims of descriptive linguistics as opposed to the prescriptive discourse of macro-level curriculum policy, they are still often used in meaningless ways in order to give the impression of policies that are sociolinguistically astute (see Godley \& Reaser 2018:34 and Fairclough 2013:33-56 for a critical discussion on language 'appropriateness'). What discourse such as this suggests, then, is that meso-level policy arbiters are unaware of the 'situated creation of social meaning' and the role that language plays in this, in how different social spaces can provide speakers with opportunities to draw on different linguistic repertoires in order to build inter-group relationships and identity profiles (Snell 2018b).

Whilst linguists would generally not disagree with the reality of register, what many of the policies as reported on appear to suggest is that spaces - or 'formal language zones' (Fishwick 2013) - have clearly delineated boundaries, each of which demands a different linguistic code. The disruption of these arbitrary boundaries was seen to be a problematic issue, in the 'risk' that it carried in terms of children 'becoming confused'.

if children are talking in slang to their mates in the playground ... when it comes to English lessons it can be very confusing. (Dixon 2013)

yeah it's fine to use slang outside or at home I think (1) but in my classroom I don't really want that in there (.) it's not the right place to use that kind of language or bad grammar (Seth)

Many policies appeared to have contradictory or ill-defined messages about why, where, or when different varieties of language were appropriate - with some suggesting schools had 'banned any slang or incorrect from [my] classroom but I 
generally don't bother if I hear it in the playground' (Claudia), or had 'asked students to use standard English inside the school gates' on the grounds that 'the street stops at the gate' (Shepherd 2012). Here then, policies define spaces as having neatly defined edges, and attempt to apply the same idea to language and its varieties. Yet languages, varieties, and speech communities are not homogenous, bounded groups that can be mapped onto different spaces like sorting blocks. Insisting on linguistic borders within language policy is an arbitrary decision that can legitimise practices of 'belonging' and 'not belonging' and establish margins of exclusion - especially in educational settings (e.g. Valdés 2017). Rather than seeing children's language as something that ought to be policed and 'borderised', an alternative way of thinking would conceptualise children's linguistic repertoires as flexible resources that can be used in multiple ways (Snell 2013).

D I S C U S S I O N, I M P L I C A T I O N S, A N D

C O N C L U S I O N

Language education policies are powerful tools that can impose sanctions and regulations, turning language ideologies into language practices (Shohamy 2006). This article has critically examined policies that are driven by regulation and stigmatisation, tracing textual points of contact across different policy levels and unpicking the justifications given for their design and implementation. Within and across each of these levels, language policing is a pervasive practice that policy arbiters engage in across all levels, legitimised in particular by the linguistic conservatism and linguicism of current UK curriculum policy.

Policies that feature language policing index language to clusters of other factors, most notably academic achievement, employability, economic success, crime, and space. Language as a proxy for other factors has long been discussed in critical approaches to language stigmatisation (e.g. Cameron 1995), language rights (e.g. Wee 2011), as well as identities and variation (e.g. Eckert 2008) but has received limited attention in $\mathrm{L} 1$ educational language policy research, especially through a critical discursive approach. In the sections above, I have examined how micro- and meso-levels of policy appear to be shaped and governed by current conditions of macro-level policy and given a platform through uncritical media discourse that is lacking in sociolinguistic knowledge. I am not suggesting that all instances of language policing are a direct result of current curriculum policy or media discourse, acknowledging that this would be a gross over-simplification of how policy levels interact with each other (Johnson 2009). Similarly, I am of course not suggesting that all teachers engage in such policies - there are many teachers who resist the imposition of macro-level linguicism and employ meaningful, linguistically democratic policies into their classrooms.

Whilst macro-level policies and media discourse have provided a platform for linguicism then, they are not the sole reason for the existence of language policing. Macro-level policies are one factor in a complex assemblage of mediating factors, 
from the typically limited level of teachers' linguistic knowledge (e.g. Cajkler \& Hislam 2002), a general lack of criticality within educational linguistics (see Godley \& Reaser 2018), to other pressures faced by schools such as the 'performativity agenda' (Ball 2003). In this, schools operate within a competitive, marketised system of high-stakes regimes that include the cross-comparative judging of schools in terms of examination results. Indeed, many of the policies examined in the data were often reported to be implemented as a reactionary measure against government inspection agencies and the Teachers' standards (Department for Education 2013c). When schools feel pressure and are described using the evaluative discourse of inspection - for example, 'failing' or 'requires improvement', they can often implement 'policies of compliance' (Perryman et al. 2018) that are typically designed in order to appease government inspectors rather than enact the genuine views of teachers and school management. As such, teachers can be coerced into acting as mouthpieces for the UK government's conservative and prescriptive language ideologies.

After reading the media coverage of language policing, one might be forgiven for assuming that young people's written and spoken language in schools is characterised by a high frequency of nonstandardised forms. Although such data from the schools in this study is not available, it would certainly be surprising if this was indeed the case, given that research has demonstrated that young people's language in schools makes use of relatively little nonstandardised forms. For instance, studies in Tyneside (Williamson 1995) showed that nonstandardised forms made up around $6 \%$ of usage, and similar numbers were reported for data from London, Merseyside, and the South West of England (Williamson \& Hardman 1997a,b). Further research is needed in order to better understand the impact, if any, of nonstandardised forms on academic achievement. What the articles and the policies do appear to be a form of, then, is a version of Cameron's (1995) moral panic and Lippi-Green's (2012) subordination process, whipped up by macro-level curriculum changes and the increasingly available presence of conservative discourse and practices within educational policy and sensationalist media.

It is important to repeat that my criticism here is not specifically directed at teachers but at wider systemic issues concerning the limited presence of linguistics within teacher education, the lack of government funding in providing opportunities for teachers to develop their own subject knowledge, and punitive language ideologies stemming from current government policy. Despite these challenges, many linguists continue to engage with teachers in designing pedagogical materials, websites, courses, and readings that focus on variation and attitudes to language (e.g. Cheshire \& Fox 2016; Giovanelli \& Clayton 2016; Godley \& Reaser 2018), as well as the innovative content of the post-sixteen 'A-level' English language qualification in the UK, which has sociolinguistics at its heart (e.g. AQA 2015). However, politicians have resisted much insight and expertise from linguists ${ }^{5}$ (most notably perhaps in the case of LINC), and so engaging with policy makers at the macro-level remains a challenging issue, especially when macro-level 
ideologies about language are so caught up in maintaining standards, accountability measures, and high-stakes assessments. Prior to A-level, opportunities for young people to study sociolinguistics in UK schools are limited and have been reduced by current educational policy - for instance, a popular unit at GCSE (ages fourteen to sixteen) level in the UK about spoken language and language attitudes was removed by Michael Gove in favour of 'traditional' grammar and canonical literature (see Clayton 2013, 2016). A useful avenue for future work would be for sociolinguists to work with teachers in order to be more critically engaged with language and offer solutions for change (see Alim 2010), as would be ethnographic work in schools in order to trace the 'social life' of language policies and better understand the experiences of those who are part of them. Although the data discussed in this article derives from a relatively small number of cases, it is highly likely that other educational institutions have implemented language policies designed to monitor and regulate language use. In addition, the connections between US and UK language policies, which I have touched on this article, would also be of interest for future research, as would a rigorous critique of the primary school grammar tests and the way that they impose 'control' (Shohamy 2001) over language ideologies and pedagogies.

This article began by drawing on Carter's dentist metaphor as a way of framing how teachers can be coerced into operating as prescriptive language policy arbiters, working within systems of macro-level control and standards that describe language as it SHOULD be, rather than how it actually is. In applying a critical discursive approach to a range of data sources in order to understand how different policy levels interact and relate to each other, I have shown how recent instances of language policing may be a result of a synergy of top-down policy pressures and prescriptive discourse on curriculum policy. Combined with issues surrounding teacher education and the role of the media in re/producing misconceptions of language, it appears that the 'extracting', 'polishing', and 'straightening out' of young people's language by powerful policy arbiters is a practice that perhaps requires a different set of metaphorical terms: that of policing, punishment, and crime.

\section{N O T E S}

*Thank you to Jenny Cheshire and to two anonymous reviewers for their constructive and helpful comments on an earlier version of this article. Thank you also to Elisabeth Barakos for her comments much earlier in the process, and to the teachers who took part in the interviews.

${ }^{1}$ The review of primary assessments was led by a professor of politics, Lord Paul Bew. David Crystal, a linguist at Bangor University, and Debra Myhill, an educational linguist at the University of Exeter later raised serious concerns about the tests in their role on the review panel in 2013 (Myhill, p.c.). These were not addressed by government.

${ }^{2}$ Lemov is the managing director of 'Teach like a champion', with close links to the Uncommon Schools network of charter schools in the US, and ARK schools in the UK. Both are known for their strict 'no excuses' authoritarian policies, with pedagogies geared around the teacher-led delivery of 'core knowledge'. They are frequently held up as examples of successful schools by education ministers in the UK. 


\section{IAN CUSHING}

${ }^{3}$ See, for example, Lawton (2013).

${ }^{4}$ For instance, Nick Gibb, the current Minister of State for School Standards, appeared on BBC television on the 18 June 2019 to defend a schools' zero-tolerance language policy. He claimed that fillers such as 'um' and 'err' are a 'sign of a lack of confidence' and that such policies would allow students to 'take part in a formal interview' in later life.

${ }^{5}$ In June 2016, Michael Gove appeared on Sky News and declared that 'people have had enough of experts'.

\section{R E F E R E N C E S}

Alim, Samy (2010). Critical language awareness. In Nancy Hornberger \& Sandra McKay (eds.), Sociolinguistics and language education, 205-321. Clevedon: Multilingual Matters.

Amir, Alia, \& Nigel Musk (2013). Language policing: Micro-level language policy-in process in the foreign language classroom. Classroom Discourse 4(2):151-67.

Anonymous (2016). SPEAK PROPERLY! Towie language banned from school so pupils can get a job. Daily Express. Online: https://www.express.co.uk/news/uk/665793/towie-essex-language-bannedschool-Ongar-Academy.

AQA (2015). AS and A-level English language. Manchester: AQA.

Awford, Jenny (2014). Ban on Black Country slang has improved reading and writing claims controversial primary school which sparked anger by pulling up pupils on local dialect. Mail Online. Online: https://www.dailymail.co.uk/news/article-2791261/ban-black-country-slang-improved-readingwriting-claims-controversial-primary-school-sparked-anger-pulling-pupils-local-dialect.html.

Ball, Stephen (2003). The teacher's soul and the terrors of performativity. Journal of Education Policy 18(2):215-28.

Barakos, Elisabeth, \& Johann Unger (eds.) (2016a). Discursive approaches to language policy. London: Palgrave.

- \& — (2016b). Introduction: Why are discursive approaches to language policy necessary? In Barakos \& Unger (2016a), 1-10.

Baratta, Alex (2018). Accent and teacher identity in Britain: Linguistic favourism and imposed identities. London: Bloomsbury.

Board of Education (1921). The teaching of English in England (The Newbolt report). London: HMSO. Bourdieu, Pierre (1991). Language and symbolic power. Cambridge: Polity Press.

Brady, Jude (2015). Dialect, power and politics: Standard English and adolescent identities. Literacy 49 (3):149-57.

Bucholtz, Mary, \& Kira Hall (2005). Identity and interaction: A socio-cultural linguistic approach. Discourse Studies 7(5):585-614.

Cajkler, Wasyl, \& Jane Hislam (2002). Trainee teachers' grammatical knowledge: The tension between public expectations and individual competence. Language Awareness 11(3):161-77.

Cameron, Deborah (1995). Verbal hygiene. London: Routledge.

Carter, Ronald (1994). Standard Englishes in teaching and learning. In Mike Hayhoe \& Stephen Parker (eds.), Who owns English?, 60-77. Buckingham: Open University Press.

(1996). Politics and knowledge about language: The LINC project. In Ruqaiya Hasan \& Geoff Williams (eds.), Literacy in society, 1-8. Harlow: Longman.

- (1997). Investigating English discourse: Language, literacy and culture. London: Routledge.

Chadderton, Charlotte (2014). The militarisation of English schools: Troops to teaching and the implications for initial teacher education and race equality. Race Ethnicity and Education 17(3):407-28.

Cheshire, Jenny (1982). Dialect features and linguistic conflict in schools. Educational Review 34(1):53-67.

Cheshire, Jenny, \& Sue Fox (2009). Was/were variation: A perspective from London. Language Variation and Change 21:1-38. 


\section{THE POLICY AND POLICING OF LANGUAGE IN SCHOOLS}

\& - (2016). From sociolinguistic research to English language teaching. In Karen P. Corrigan \& Adam Mearns (eds.), Creating and digitizing language corpora, vol. 3: Databases for public engagement, 265-90. Basingstoke: Palgrave Macmillan.

Clark, Urszula (2001) War words: Language, history and the disciplining of English. Oxford: Elsevier. (2010). Grammar in the curriculum for English: What next? Changing English 17(2):189-200.

Clayton, Dan (2013). Not rigorous, just wrong: Gove's English language. Teaching English 3:54-57. (2016). Attitudes to language change and variation. In Giovanelli \& Clayton, 77-89.

Common Core State Standards (2010). Common Core State Standards for English language arts and literacy in history/social studies, science and technical subjects. Online: http://www.corestandards.org/ wp-content/uploads/ELA_Standards1.pdf.

Crowley, Tony (2003). Standard English and the politics of language. Basingstoke: Palgrave Macmillan.

Curtis, Joseph (2016). Shut up! Geezer who runs Essex school is like 'pupils must stop speaking as if they were in Towie'. Mail Online. Online: https://www.dailymail.co.uk/news/article-3565133/ Shut-Geezer-runs-Essex-school-like-pupils-stop-speaking-Towie.html.

Cushing, Ian (2018). Grammar policy and pedagogy from primary to secondary school. Literacy 53(3):170-79.

(2019). Resources not rulebooks: Metaphors for grammar in teachers' metalinguistic discourse. Metaphor and the Social World 9(2):155-76.

Department for Education (2011). Independent review of key stage 2 testing, assessment and Accountability. London: Department for Education.

(2012). Routes into teaching. Online: https://getintoteaching.education.gov.uk/explore-myoptions/teacher-trainingroutes/university-led-training/university-led-undergraduate-training/troopsbursary.

(2013a). The national curriculum in England: Key stages 1 and 2 framework document. London: Department for Education.

(2013b). The national curriculum in England: Key stages 3 and 4 framework document. London: Department for Education.

- (2013c). Teachers' standards. London: Department for Education.

Department for Children, Schools, and Families (2009). Safer schools partnerships guidance. London: Department for Children, Schools, and Families.

Dixon, Hayley (2013). Midlands primary school bans pupils from using Black Country dialect. The Telegraph. Online: https://www.telegraph.co.uk/education/educationnews/10449085/Midlandsprimary-school-bans-pupils-from-using-Black-Country-dialect.html.

Duchêne, Alexandre, \& Monica Heller (eds.) (2012). Language in late capitalism: Pride and profit. London: Routledge.

Eckert, Penelope (2008). Variation and the indexical field. Journal of Sociolinguistics 12(4):453-76.

Elliot, Victoria (2018). Thinking about the coding process in qualitative data analysis. The Qualitative Report 23(11):2850-61.

English, Fiona, \& Tim Marr (2015). Why do linguistics? Reflective linguistics and the study of language. London: Bloomsbury.

Fairclough, Norman (2013). Critical language awareness. London: Routledge.

- (2014). Language and power. London: Routledge.

Feltz, Vanessa (2008). I award top marks to this school's slang ban. Daily Express.

Fishwick, Carmen (2013). London school bans pupils from using 'innit', 'like', and 'bare'. The Guardian. Online: https://www.theguardian.com/uk-news/2013/oct/15/london-school-bans-pupils-slang-innit.

Fowler, Roger (1991). Language in the news: Discourse and ideology in the press. London: Routledge.

Fricker, Martin (2013). Yow cor spaek lyuke that! West Midlands school bans pupils from using 'damaging' regional slang. The Mirror. Online: https://www.mirror.co.uk/news/uk-news/black-countryslang-banned-halesowen-2791066. 


\section{IAN CUSHING}

Garrett, Peter; Nikolas Coupland; \& Angie Williams (1999). Evaluating dialect in discourse: Teachers' and teenagers' responses to young English speakers in Wales. Language in Society 28(3):321-54.

Garvis, Susanne (2015). Narrative constellations: Exploring lived experience in education. Rotterdam: Sense Publishers.

Gee, James Paul (2012). Social linguistics and literacies: Ideology in discourse. London: Routledge.

Gibb, Nick (2018). Our reforms to primary education are beginning to work. Here's the evidence. Online: https://www.conservativehome.com/platform/2018/11/nick-gibb-our-reforms-to-primary-education-are-beginning-to-work-heres-the-evidence.html.

Gibbons, Simon (2017). English and its teachers: A history of policy, pedagogy and practice. London: Routledge.

Gillborn, David (2006). Citizenship education as placebo: 'Standards', institutional racism and education policy. Education, Citizenship and Social Justice 1(1):1-16.

Giovanelli, Marcello (2016). The value of linguistics to the teacher. In Giovanelli \& Clayton, 13-24.

- \& Dan Clayton (eds.) (2016). Knowing about language: Linguistics and the secondary English classroom. London: Routledge.

Godley, Amanda; Brian Carpenter; \& Cynthia Werner (2007). 'I'll speak in proper slang': Language ideologies in a daily editing activity. Reading Research Quarterly 42:100-31.

- \& Jeffrey Reaser (2018). Critical language pedagogy: Interrogating language, dialects and power in teacher education. New York: Peter Lang.

Gove, Michael (2013). The importance of teaching. London: Department of Education.

(2014). An education system which works for every child. London: Department of Education.

Griffiths, Sian, \& Julia Henry (2019). Like it or not, they can't stop saying it on Love Island. The Times.

Hart, Christopher (2014). Discourse, grammar and ideology: Functional and cognitive perspectives. London: Bloomsbury.

Heller, Monica (2001). Undoing the macro/micro dichotomy: Ideology and categorisation in a linguistic minority school. In Nikolas Coupland, Srikant Sarangi, \& Christopher N. Candlin (eds.), Sociolinguistics and social theory, 212-34. London: Longman.

Henry, Julia (2008). School bans youth slang and sees exam results soar. The Telegraph. Online: https:// www.telegraph.co.uk/education/2435923/School-bans-youth-slang-and-sees-exam-results-soar.html.

Henshall, Amanda (2018). On the school beat: Police officers based in English schools. British Journal of Sociology of Education 39(5):593-606.

Holborow, Marnie (2015). Language and neoliberalism. London: Routledge.

Huddleston, Rodney, \& Geoffrey K. Pullum (2002). The Cambridge grammar of the English language. Cambridge: Cambridge University Press.

Hudson, Richard (2001). Grammar-teaching and writing skills: The research evidence. Syntax in the Schools 17:1-6.

- (2016). The impact of policy on language teaching in UK schools. In Giovanelli \& Clayton, 25-35.

Jaworski, Adam (2018). Language in the media: Authenticity and othering. In Sally Johnson \& Astrid Ensslin (eds.), Language in the media: Representations, identities, ideologies, 345-56. London: Bloomsbury.

Johnson, David (2009). Ethnography of language policy. Language Policy 8:139-59.

(2013a). Language policy. London: Palgrave.

(2013b). Positioning the language policy arbiter. In James Tollefson (ed.), Language policies in education: Critical issues, 116-36. London: Routledge.

(2015). Intertextuality and language policy. In Francis Hult \& David Johnson (eds.), Research methods in language policy and planning, 166-80. Oxford: Blackwell.

Jones, Ken (2014). Conservatism and educational crisis: The case of England. Educational Inquiry 5(1):89-108.

Jones, Rodney (2017). Surveillant landscapes. Linguistic Landscape 3(2):149-86. 


\section{THE POLICY AND POLICING OF LANGUAGE IN SCHOOLS}

Jones, Toni (2013). Shaaht aahp! The Essex accent is revealed to be the worst in Britain as women admit to swooning over a soft Irish twang. Mail Online. Online: https://www.dailymail.co.uk/femail/article2266574/Shut-UP-The-Essex-accent-revealed-worst-Britain-women-admit-swooning-soft-Irishtwang.html.

Kafka, Judith (2011). The history of 'zero tolerance' in American public schooling. New York: Palgrave. Lakoff, George, \& Mark Johnson (1980). Metaphors we live by. Chicago: University of Chicago Press.

Lawton, Rachele (2013). Speak English or go home: The anti-immigrant discourse of the American 'English only' movement. Critical Approaches to Discourse Analysis Across Disciplines 7(1):100-22.

Lemov, Doug (2010). Teach like a champion: 49 techniques that put students on the right path to college. San Francisco, CA: Jossey-Bass.

Levey, Stephen (2012). Understanding children's non-standard spoken English: A perspective from variationist sociolinguistics. Language and Education 26(5):405-21.

Lippi-Green, Rosina (2012). English with an accent: Language, ideology and discrimination in the United States. London: Routledge.

MacRuairc, Gerry (2011a). They're my words - I'll talk how I like! Examining social class and linguistic practice among primary school children. Language and Education 25(6):535-59.

(2011b). Where words collide: Social class, school and linguistic discontinuity. British Journal of Sociology of Education 32(4):541-61.

Mansell, Warwick (2017). Battle on the adverbials front: Grammar advisers raise worries about Sats tests and teaching. The Guardian. Online: https://www.theguardian.com/education/2017/may/09/frontedadverbials-sats-grammar-test-primary.

Milroy, James (2001). Language ideologies and the consequences of standardization. Journal of Sociolinguistics 5(4):530-55.

Milroy, Lesley (1999). Standard English and language ideology in Britain and the United States. In Tony Bex \& Richard Watts (eds.), Standard English: The widening debate, 173-206. London: Routledge.

Moore, Emma (2011). Variation and identity. In Warren Maguire \& April McMahon (eds.), Analysing variation in English, 219-36. Cambridge: Cambridge University Press.

Mortimer, Katherine, \& Stanton Wortham (2015). Analyzing language policy and social identification across heterogeneous scales. Annual Review of Applied Linguistics 35:160-72.

Muth, Sebastian, \& Alfonso Del Percio (2018). Policing for commodification: Turning communicative resources into commodities. Language Policy 17(2):129-35.

Ongar Academy (2016). School receives national recognition for new initiative. Online: http://www. theongaracademy.org/school-receives-national-recognition-new-initiative/.

Park, Joseph Sung-Yul, \& Lionel Wee (2012). Markets of English: Linguistic capital and language policy in a globalizing world. London: Routledge.

Paton, Graeme (2009). Police officers 'should patrol every school'. The Telegraph. Online: https://www. telegraph.co.uk/education/educationnews/4538019/Police-officers-should-patrol-every-school.html.

Pennycook, Alastair (2001). Critical applied linguistics. London: Routledge.

Perryman, Jane; Meg Maguire; Annette Braun; \& Stephen Ball (2018). Surveillance, governmentality and moving the goalposts: The influence of Ofsted on the work of schools in a post-panoptic era. British Journal of Educational Studies 66(2):145-63.

Piller, Ingrid (2016). Linguistic diversity and social justice. Oxford: Oxford University Press.

Poza, Luis, \& Guadalupe Valdés (2017). Assessing English language proficiency in the United States. In Elana Shohamy, Iair Or, \& Stephen May (eds.), Language testing and assessment, 427-40. New York: Springer.

Press Association (2013). Head defends dialect ban in class. The Independent.

Ricento, Thomas, \& Nancy Hornberger (1996). Unpeeling the onion: Language planning and policy and the ELT professional. TESOL Quarterly 30(3):401-27.

Rosa, Jonathan, \& Nelson Flores (2017). Unsettling race and language: Toward a raciolinguistic perspective. Language in Society 46(5):621-47. 


\section{IAN CUSHING}

Semino, Elena (2008). Metaphor in discourse. Cambridge: Cambridge University Press.

Shepherd, Jessica (2012). Hiya pupils, please avoid slang, ta. The Guardian. Online: https://www. theguardian.com/education/2012/feb/14/hiya-pupils-avoid-slang-sheffield.

Shohamy, Elana (2001). The power of tests: A critical perspective on the uses of language tests. Singapore: Longman.

(2006). Language policy: Hidden agendas and new approaches. London: Routledge.

Skutnabb-Kangas, Tove (1988). Multilingualism and the education of minority children. In Tove Skutnabb-Kangas \& James Cummins (eds.), Minority education: From shame to struggle, 9-44, Clevedon: Multilingual Matters.

Snell, Julia (2013). Dialect, interaction and class positioning at school: From deficit to different to repertoire. Language and Education 27(2):110-28.

(2018a). Critical reflections on the role of the sociolinguist in UK language debates. Language in Society 47(3):368-74.

(2018b). Solidarity, stance and class identities. Language in Society 47(5):665-91.

, \& Richard Andrews (2016). To what extent does a regional dialect and accent impact on the development of reading and writing skills? Cambridge Journal of Education 47(3):297-313.

Trudgill, Peter (1975). Accent, dialect and the school. London: Edward Arnold.

Tyler, Imogen (2013). Revolting subjects: Social abjection and resistance in neoliberal Britain. London: Zed Books.

Valdés, Guadalupe (2017). Entry visa denied: The construction of symbolic language borders in educational settings. In Ofelia García, Nelson Flores, \& Massimiliano Spotti (eds.), The Oxford handbook of language and society, 321-48. Oxford: Oxford University Press.

Van Mensel, Luk; Mieke Vandenbrouke; \& Robert Blackwood (2017). Linguistic landscapes. In Ofelia García, Nelson Flores, \& Massimiliano Spotti (eds.), The Oxford handbook of language and society, 423-50. Oxford: Oxford University Press.

Watts, Richard (1999). The social construction of standard English: Grammar writers as a 'discourse community'. In Tony Bex \& Richard Watts (eds.), Standard English: The widening debate, 40-68. London: Routledge.

Weale, Sally (2014). The American who wrote Britain's latest teaching bible. The Guardian. Online: https://www.theguardian.com/education/2014/oct/12/american-wrote-classroom-bible-doug-lemov.

Wee, Lionel (2011). Language without rights. Oxford: Oxford University Press.

Williamson, John (1995). Canny writers: Tyneside dialect and the writing of secondary school students. Educational Studies 21(1):3-12.

— \& Frank Hardman (1997a). To purify the dialect of the tribe: Childrens' use of nonstandard dialect grammar in writing. Educational Studies 23:157-68.

— \& — (1997b). Those terrible marks of the beast: Nonstandard dialect and children's writing. Language and Education 11:287-99.

Woolard, Kathryn, \& Bambi Schieffelin (1994). Language ideology. Annual Review of Anthropology 23:55-82.

Yandell, John (2017). Culture, knowledge and power: What the Conservatives have learnt from E. D. Hirsch. Changing English 24(3):246-52.

(Received 7 March 2019; revision received 3 July 2019; accepted 30 July 2019; final revision received 31 July 2019)

Address for correspondence: Ian Cushing Department of Education Brunel University London Uxbridge, UB8 3PH, UK ian.cushing@brunel.ac.uk 